MODELING, IDENTIFICATION AND CONTROL, 2003, vOL. 24, No. 4, 205-216

doi:10.4173/mic.2003.4.2

\title{
The Impact of Varying Conductivity on the Control of Aluminium Electrolysis Cells*
}

\author{
TORMOD DRENGSTIG $\dagger$, STEINAR KOLÅSł and \\ TROND STØRE $\ddagger$
}

Keywords: Aluminium electrolysis, excess $\mathrm{AlF}_{3}$, control, bath temperature

\begin{abstract}
In this paper we investigate from a theoretical point of view the impact of varying bath temperature, excess $\mathrm{AlF}_{3}$ and alumina concentration on cell resistance and cell control. The results are interpreted using knowledge of the behavior of general resistance and anode beam controllers to study the influence on the anode cathode distance. This again leads to the proposal of a new control strategy for bath temperature and excess $\mathrm{AlF}_{3}$. The theoretical results obtained are supported using real data.
\end{abstract}

\section{Nomenclature}

$\begin{array}{lll}i_{a} & \text { anodic current density } & {\left[\mathrm{A} / \mathrm{cm}^{2}\right]} \\ \kappa & \text { conductivity } & {[1 /(\Omega \mathrm{cm})]} \\ \mathrm{ACD} & \text { anode-cathode-distance } & {[\mathrm{cm}]} \\ d_{b} & \text { bubble thickness } & {[\mathrm{cm}]} \\ T_{C} & \text { bath temperature in Celsius } & {\left[{ }^{\circ} \mathrm{C}\right]} \\ T_{K} & \text { bath temperature in Kelvin } & {[\mathrm{K}]} \\ w_{\mathrm{AlF}_{3}} & \text { concentration in } \mathrm{AlF}_{3} & {[\mathrm{wt} \%]} \\ w_{\mathrm{Al}_{2} \mathrm{O}_{3}} & \text { concentration of } \mathrm{Al}_{2} \mathrm{O}_{3} & {[\mathrm{wt} . \%]} \\ w_{\mathrm{LiF}} & \text { concentration of } \mathrm{LiF} & {[\mathrm{wt} . \%]} \\ \phi & \text { farction of anode covered by bubbles } & {[-]} \\ a_{\mathrm{Al}{ }_{2} \mathrm{O}_{3}} & \text { activity of alumina } & {[-]} \\ p_{\mathrm{CO}} & \text { partial pressure of CO } \\ R & \text { universal gas constant } & {[-]} \\ F & \text { Faraday's number } & {[\mathrm{J} /(\mathrm{mol} \mathrm{K})]} \\ i_{c c} & \text { critical current density } & {\left[\mathrm{C} / \mathrm{mol}_{2}\right]} \\ i_{r} & \text { limiting current density } & {\left[\mathrm{A} / \mathrm{cm}^{2}\right]} \\ i_{c} & \text { cathodic current density } & {\left[\mathrm{A} / \mathrm{cm}^{2}\right]} \\ R_{m} & \text { measured cell resistance } & {\left[\mathrm{A} / \mathrm{cm}^{2}\right.} \\ U_{\text {cell }} & \text { overall cell voltage } & {[\Omega]} \\ U_{\text {bath }} & \text { ohmic bath potential } & {[\mathrm{V}]} \\ U_{\text {bubble }} & \text { bubble layer potential } & {[\mathrm{V}]} \\ U_{\text {ext }} & \text { external cell arrangement potential } & {[\mathrm{V}]} \\ A_{a n} & \text { Cross sectional area of a single anode } & {[\mathrm{V}]} \\ D_{s n} & \text { Cell design factor } & {\left[\mathrm{cm}{ }^{2}\right]} \\ & & {[-]}\end{array}$

\footnotetext{
*Presented at Light Metals 2002, Seattle, Washington, USA.

$\dagger$ Department of Electrical and Computer Engineering, Stavanger University College, N-4091 Stavanger, Norway.

$\ddagger$ Hydro Aluminium Technology Center, N 6881 Øvre Årdal, Norway
} 


\begin{tabular}{|c|c|}
\hline & $\begin{array}{l}\mathrm{NaF} / \mathrm{AlF}_{3} \text { weight ratio } \\
\text { anode baking temperature }\end{array}$ \\
\hline$\eta_{c a}$ & anodic concentration overvoltage \\
\hline$\eta_{a a}$ & anodic surface overvoltage \\
\hline$\eta_{c c}$ & cathodic concentration overvoltage \\
\hline$E_{\text {rev }}$ & reversible cell potential \\
\hline$E^{\mathrm{o}}$ & standard potential of cell reaction \\
\hline$w_{\mathrm{Al}_{2} \mathrm{O}_{3}, \mathrm{AE}}$ & alumina concentration at anode effect \\
\hline$w_{\mathrm{Al}_{2} \mathrm{O}_{3} \text {, sat }}$ & $\begin{array}{l}\text { no. of electrons involved in a reaction } \\
\text { saturated alumina concentration }\end{array}$ \\
\hline $\begin{array}{l}w_{\mathrm{Al}_{2} \mathrm{O}_{3}, \mathrm{sat}} \\
\operatorname{ROS}\end{array}$ & $\begin{array}{l}\text { saturated alumina concentration } \\
\text { ratio of saturation }\end{array}$ \\
\hline
\end{tabular}

\section{Introduction}

In the literature there are a large number of publications presenting results on how the conductivity of cryolitic melts varies as a function of temperature and chemical composition, see for instance Aaberg et al. (1997), Danek et al. (1995), Haupin (1998) and Hyde \& Welch (1997). In this paper the implicit effect of varying conductivity on cell control is investigated. Cell control here means alumina concentration control, excess $\mathrm{AlF}_{3}$ control and bath temperature control.

The strong relationship between bath temperature and excess $\mathrm{AlF}_{3}$ is shown in publications by Desclaux (1987), Entner (1992), (1993), (1995), Entner \& Gudmundsson (1996), Peyneau (1988), Taylor (1992) and Wilson (1992), though the results from the work of Drengstig (1997) demonstrated that disturbances in the energy balance is the main reason for variations in both excess $\mathrm{AlF}_{3}$ and bath temperature.

Based upon this knowledge, Drengstig et al. (1998) presented a novel control strategy for excess $\mathrm{AlF}_{3}$ and bath temperature where it is suggested to maintain the mass balance of $\mathrm{AlF}_{3}$, instead of maintaining excess $\mathrm{AlF}_{3}$, by using an almost constant $\mathrm{AlF}_{3}$ input, and to use energy input, i.e. anode beam movements, to compensate for the energy disturbances.

However, in many cell lines the energy input is squeezed to a minimum, and a further reduction of the reference resistance, or the anode-cathode-distance (ACD), is believed to result in reduced current efficiency and unstable cells. On the other hand, this paper shows theoretically that the behavior of the aluminum cell including its controllers is such that the proposed control strategy in Drengstig et al. (1998) is most likely implementable. The theoretical results are supported using real data.

\section{Theoretical basis}

The overall cell voltage, $U_{\text {cell }}$, is a sum of several ohmic and non-ohmic voltages

$$
U_{\text {cell }}=\sum_{i} U_{\text {ohmic }, i}+\sum_{j} E_{\text {non-ohmic } . j}
$$

The ohmic part may be divided into a bath potential, $U_{\text {bath }}$. a potential due to the bubble layer underneath the anodes, $U_{\text {bubble }}$, and a potential of the external cell arrangement, $U_{\text {ext }}$. This latter potential is typically in the range between 0.7 and $0.8 \mathrm{~V}$. 
The non-ohmic potential consists of the reversible (equilibrium) cell potential, $E_{\text {rev }}$, and reaction and concentration overvoltages. The overall cell voltage $U_{\text {cell }}$ then becomes

$$
U_{\text {cell }}=U_{\text {bath }}+U_{\text {bubble }}+U_{\text {ext }}+\left|E_{\text {rev }}\right|+\left|\eta_{a a}\right|+\left|\eta_{a c}\right|+\left|\eta_{c c}\right|
$$

In the following these terms are investigated in more detail.

Ohmic bath voltage, $U_{\text {bath }}$

The ohmic bath voltage, $U_{\text {bath }}$, is linearly dependent on the ACD as

$$
U_{\text {bath }}=\frac{i_{a}}{\kappa} \cdot\left(\mathrm{ACD}-d_{b}\right)
$$

Under normal operating conditions the ACD is between 4 and $5 \mathrm{~cm}$. The conductivity, $\kappa$, of the electrolyte can for instance be found from Chrenkova et al. (1996) as

$$
\begin{aligned}
\kappa= & -7.332+1.742 \cdot 10^{-2} \cdot T_{C}-7.313 \cdot 10^{-6} \cdot T_{C}^{2}-1.866 \cdot 10^{-4} \cdot w_{\mathrm{AIF}}^{2} \\
& -2.824 \cdot 10^{-5} \cdot w_{\mathrm{AlF}_{3}} \cdot T_{C}+4.613 \cdot 10^{-2} \cdot w_{\mathrm{LiF}}+2.046 \cdot 10^{-4} \cdot w_{\mathrm{LiF}}^{2} \\
& -4.695 \cdot 10^{-5} \cdot w_{\mathrm{Al}_{2} \mathrm{O}_{3}} \cdot T_{\mathrm{C}}+2.462 \cdot 10^{-4} w_{\mathrm{AlF}_{3}} \cdot w_{\mathrm{LiF}} \\
& +2.003 \cdot 10^{-3} w_{\mathrm{AlF}_{3}} \cdot w_{\mathrm{Al}_{2} \mathrm{O}_{3}}-5.546 \cdot 10^{-5} \cdot w_{\mathrm{AIF}_{3}} \cdot w_{\mathrm{LiF}} \cdot w_{\mathrm{Al}_{2} \mathrm{O}_{3}}
\end{aligned}
$$

Bubble voltage, $U_{\text {bubble }}$

The bubble distance or bubble layer thickness is given in Haupin (1998) as

$$
d_{b}=\frac{0.5517+i_{a}}{1+2.167 \cdot i_{a}}
$$

This equation is based on data determined by Hyde \& Welch (1997) and Aaberg et al. (1997). Moreover, the fraction of the anode covered by bubbles, $\phi$, are expressed as (Haupin, 1998)

$$
\begin{aligned}
\phi= & 0.5090+0.1823 \cdot i_{a}-0.1723 \cdot i_{a}^{2}+0.05504 \cdot i_{a}^{3}+\frac{0.4322-0.3781 \cdot R_{b}}{1+1.637 \cdot R_{b}} \\
& +\frac{0.431-0.1437 \cdot\left(w_{\mathrm{Al}_{2} \mathrm{O}_{3}}-w_{\mathrm{Al}_{2} \mathrm{O}_{3}, \mathrm{AE}}\right)}{1+7.353 \cdot\left(w_{\mathrm{AlF}_{2} \mathrm{O}_{3}}-w_{\mathrm{Al}_{2} \mathrm{O}_{3}, \mathrm{AE}}\right)}
\end{aligned}
$$

This equation is based on data from Aaberg et al. (1997) and Haupin (1971). The additional voltage caused by bubbles, $U_{\text {bubble, }}$, then becomes (Haupin, 1971)

$$
U_{\text {bubblc }}=\frac{i_{a}}{\kappa} \cdot\left(\frac{d_{b}}{1-\phi}-d_{b}\right)
$$

Reversible (equilibrium) cell potential, $E_{\mathrm{rev}}$

The main reaction within an aluminum electrolysis cell is

$$
\mathrm{Al}_{2} \mathrm{O}_{3}(\mathrm{sol})+\frac{3}{2} \mathrm{C}(\mathrm{s}) \rightarrow 2 \mathrm{Al}(\mathrm{l})+\frac{3}{2} \mathrm{CO}_{2}(\mathrm{~g})
$$


The standard potential as a function of temperature, $E^{\circ}\left(T_{K}\right)$, of this reaction can be found to be

$$
E^{\circ}\left(T_{K}\right)=-1.8984+5.725 \cdot 10^{-4} \cdot T_{K}
$$

However, during normal operation the bath is not saturated with alumina. Consequently, Nernst's equation must be considered to account for this discrepancy in fulfillment of standard conditions:

$$
-z \cdot \mathscr{F} \cdot E_{\mathrm{rev}}=-z \cdot \mathscr{F} \cdot E^{\mathrm{o}}+R \cdot T_{K} \cdot \ln Q_{a}
$$

where $Q_{a}$ is the reaction quotient for reaction equation (8) given as

$$
Q_{a}=\frac{p_{\mathrm{CO}_{2}}^{3 / 2} \cdot a_{\mathrm{A1}}^{2}}{a_{\mathrm{Al}_{2} \mathrm{O}_{3}} \cdot a_{\mathrm{C}}^{3 / 2}}
$$

Assuming that $p_{\mathrm{CO}_{2}}=1, a_{\mathrm{Al}}=1$ and $a_{\mathrm{C}}=1$ gives

$$
\begin{aligned}
E_{\mathrm{rev}} & =E^{\mathrm{o}}-\frac{R \cdot T_{K}}{z \cdot \mathscr{F}} \cdot \ln \left(\frac{1}{a_{\mathrm{AL}_{2} \mathrm{O}_{3}}}\right) \\
& =E^{\mathrm{o}}+\frac{R \cdot T_{K}}{z \cdot \mathscr{F}} \cdot \ln \left(a_{\mathrm{Al}_{2} \mathrm{O} 3}\right)
\end{aligned}
$$

where $a_{\mathrm{Al}_{2} \mathrm{O}_{3}}$ is the activity of $\mathrm{Al}_{2} \mathrm{O}_{3}$. Inserting equations (9) into (12) gives the following temperature dependent cell potential at reversible, non-standard conditions:

$$
E_{\text {rev }}=-1.8984+5.725 \cdot 10^{-4} \cdot T_{K}+1.44 \cdot 10^{-5} \cdot T_{K} \cdot \ln \left(a_{\mathrm{Al}_{2} \mathrm{O}_{3}}\right)
$$

where

- $a_{\mathrm{Al}_{2} \mathrm{O}_{3}}=\operatorname{ROS}^{1.5}$ (from Haupin (1998)) and

- $\mathrm{ROS}=\frac{w_{\mathrm{Al}_{2} \mathrm{O}_{3}}}{w_{\mathrm{Al}_{2} \mathrm{O}_{3}, \text { sat }}}$

\section{Anodic concentration overvoltage, $\eta_{c a}$}

Concentration gradients in the bath close to the anode produce a concentration overvoltage (Haupin, 1998). The following expression can be used to calculate the $\eta_{c a}$.

$$
\begin{aligned}
\eta_{c a} & =\frac{R \cdot T_{K}}{2 \cdot F} \cdot \ln \left(\frac{i_{c c}}{i_{c c}-i_{u}}\right) \\
& =4.308 \cdot 10^{-5} \cdot T_{K} \cdot \ln \left(\frac{i_{c c}}{i_{c c}-i_{a}}\right)
\end{aligned}
$$

In the literature there are several different relationships for the critical current density, $i_{c c}$. For example, Haupin (1998) reports the following relationship, which is based on the early work of Piontelli et al. (1965) and augmented with later laboratory and plant data (Haupin, 1971).

$$
i_{c c}=\left(0.00464 \cdot T_{C}-3.454\right) \cdot A_{a n}^{-0.1} \cdot\left(C_{a} \cdot w_{\mathrm{Al}_{2} \mathrm{O}_{3}}+C_{b} \cdot w_{\mathrm{Al}_{2} \mathrm{O}_{3}}^{2}\right) \cdot D_{s n}
$$

where 


$$
\begin{gathered}
D_{s n}=\frac{i_{a}}{\left(0.00464 \cdot T_{C}-3.4544\right) \cdot A_{a n}^{-0.1}} \cdot \frac{1}{\left(C_{a} \cdot w_{\mathrm{Al}_{2} \mathrm{O}_{3}, \mathrm{AE}}+C_{b} \cdot w_{\mathrm{Al}_{2} \mathrm{O}_{3}, \mathrm{AE}}^{2}\right)} \\
C_{a}=1.443-1.985 \cdot R_{b}+1.131 \cdot R_{b}^{2} \\
C_{b}=0.4122-0.2037 \cdot R_{b}
\end{gathered}
$$

$D_{s n}$ compensates for different cells having anode effects at different alumina concentrations at the same current density (Haupin, 1998).

In order to calculate the $\mathrm{NaF} / \mathrm{AlF}_{3}$ weight ratio $\left(R_{b}\right)$ from excess $\mathrm{AlF}_{3}$, the following approximate relationship holds

$$
R_{b}=1.5-3.1 \cdot 10^{-2} \cdot w_{\mathrm{AlF}_{3}}
$$

Anodic surface overvoltage, $\eta_{a a}$

The anodic surface overvoltage, also referred to as reaction overvoltage $\eta_{a a}$ in Grjotheim \& Kvande (1993), can be found as

$$
\eta_{a a}=\frac{R \cdot T_{K}}{2 \cdot p \cdot F} \cdot \ln \left(\frac{i_{a}}{i_{r}}\right)
$$

where the values of $p$ correlate with the anode baking temperature (Haupin, 1998)

$$
p=\frac{3.773}{\ln \left(T_{\mathrm{AnBk}}+273\right)}
$$

The following expression is then obtained for $\eta_{a a}$ (Haupin, 1998)

$$
\eta_{a a}=1.142 \cdot 10^{-5} \cdot \ln \left(T_{\mathrm{AnBk}}+273\right) \cdot T_{K} \cdot \ln \left(\frac{i_{a}}{i_{r}}\right)
$$

where the limiting current density $i_{r}$ can be found as (Haupin, 1998)

$$
i_{r}=e^{\left(0.560 \cdot \ln \left(w_{\mathrm{Al}_{2} \mathrm{O}_{3}}+\left(w_{\mathrm{LiF}} / 4\right)\right)+0.276 \cdot\left(R_{b}-1.5\right)-5.849\right)}
$$

\section{Cathodic concentration overvoltage, $\eta_{c c}$}

The concentration overvoltage at the cathode is given as (Haupin, 1998)

$$
\eta_{c c}=1.333 \cdot 10^{-5} \cdot\left(2.73-0.5 \cdot R_{b}\right) \cdot T_{K} \cdot \ln \left(\frac{i_{c}}{0.283}\right)
$$

This equation is based on laboratory data by Thonstad \& Rolseth (1978) and scanning reference electrode data by Haupin (1971).

\section{Results}

The equations given above were implemented in Matlab and simulated under the following conditions:

- The excess $\mathrm{AlF}_{3}, w_{\mathrm{AlF}_{3}}$, varies between 6 wt. $\%$ and $16 \mathrm{wt} . \%$, whereas the bath temperature are varied between $985^{\circ} \mathrm{C}$ and $935^{\circ} \mathrm{C}$ at the same time. Hencc, the 
temperature and excess $\mathrm{AlF}_{3}$ is not varied independently, and main reason for this is the known relationship between these two variables (Drengstig, 1998).

- The concentration of $\mathrm{Al}_{2} \mathrm{O}_{3}, w_{\mathrm{Al}_{2} \mathrm{O}_{3}}$, varies between $1.2 \mathrm{wt} . \%$ and $7 \mathrm{wt} . \%$

- The anode finishing baking temperature is set to $T_{\mathrm{AnBk}}=1200^{\circ} \mathrm{C}$

- Anodic current density $i_{a}=0.9 \mathrm{~A} / \mathrm{cm}^{2}$

- The initial anode cathode distance, ACD, is $4.5 \mathrm{~cm}$

- The saturated alumina concentration in the bath is set to $w_{\mathrm{Al}_{2} \mathrm{O}_{3} \text {, sat }}=8 \mathrm{wt} . \%$ independent of temperature.

- The concentration of alumina at anode effect is set to $w_{\mathrm{Al}_{2} \mathrm{O}_{3}, \mathrm{AE}}=1.1 \mathrm{wt} . \%$.

- The concentration of $\mathrm{CaF}_{2}$ is $5 \mathrm{wt} . \%$.

- The concentration of $\mathrm{LiF}$ is set to $0 \mathrm{wt} . \%$.

\section{Conductivity as a function of varying cell conditions}

In Figure 1 the conductivity in equation (4) is presented as a function of alumina concentration, excess $\mathrm{AlF}_{3}$ and bath temperature. As can be seen, the conductivity becomes almost a flat surface in this 3-dimensional view.

\section{Components of the cell voltage}

The different components of the cell voltage, $U_{\text {cell }}$, in equation (2) is shown in Figure 2. These are $U_{\text {bath }}$ in equation (3), $U_{\text {bubble }}$ in equation (7), $E_{\text {rev }}$ in equation (13), the different overvoltages in equations (14), (22) and (24), together with the external voltage, $U_{\text {ext }}$.

By including excess $\mathrm{AlF}_{3}$ as an additional variable (and thereby also bath temperature), the 3-D view of the cell potential, $U_{\text {cell }}$, at constant ACD becomes as shown in Figure 3. As can be seen, the cell voltage have the well known curved shape along the alumina axis. Moreover, the cell voltage increases almost linearly along the

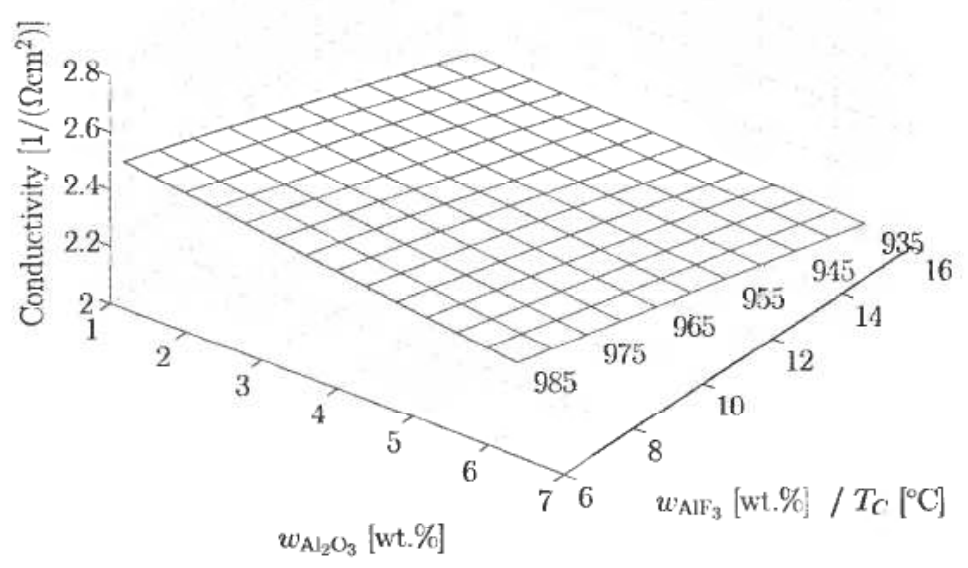

Figure 1. The conductivity $\kappa$ as a function of varying cell conditions. Note that excess $\mathrm{AlF}_{3}$ and bath temperature varies along the same axis. 
Impact of Varying Conductivity on the Control of Aluminium Electrolysis Cells 211

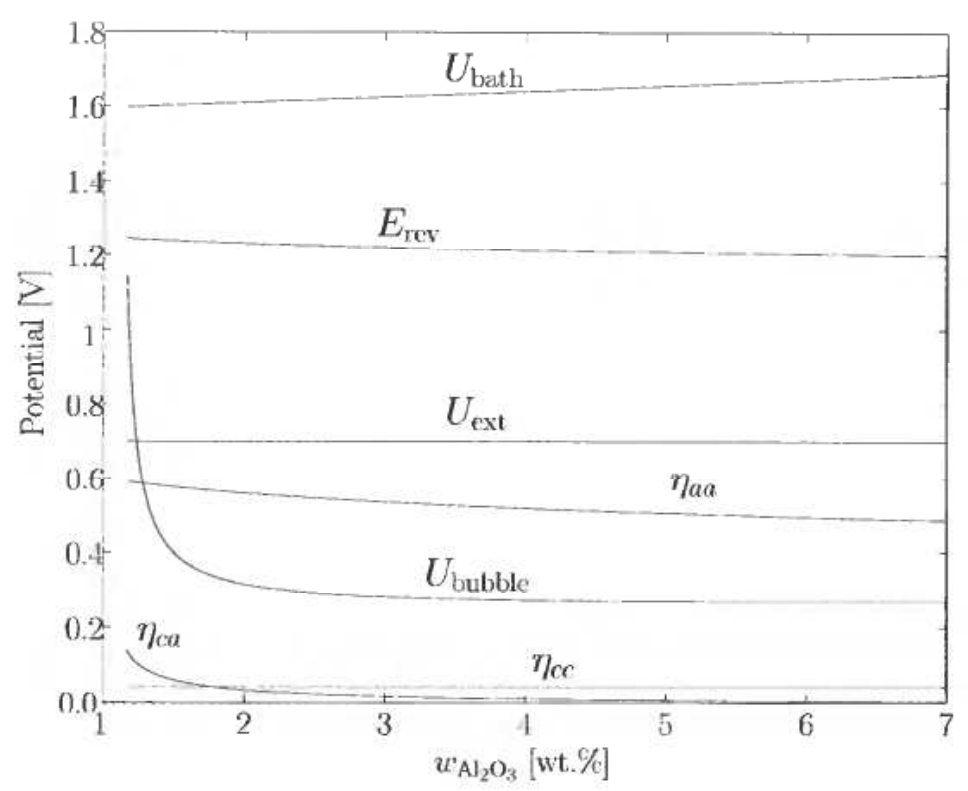

Figure 2. The different components of the overall cell voltage $U_{\text {cell }}$ as a function of alumina concentration $\left(w_{\mathrm{AlF}_{3}}=12 \mathrm{wt} . \%\right.$ and $\left.T_{\text {bath }}=955^{\circ} \mathrm{C}, \mathrm{ACD}=4.5 \mathrm{~cm}\right)$.

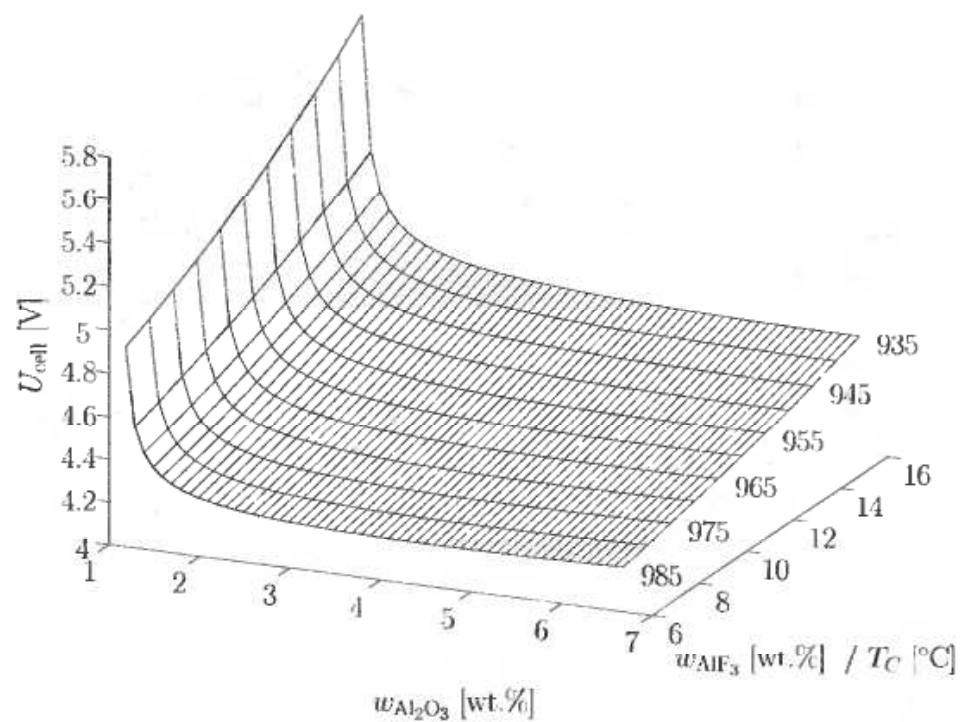

Figure 3. The overall cell voltage, $U_{\text {cell }}$, as a function of varying cell conditions, $A C D=4.5$ $\mathrm{cm}$. Note that excess $\mathrm{AlF}_{3}$ and bath temperature varies along the same axis.

excess $\mathrm{AlF}_{3}$ axis. The main reason for this is that the conductivity decreases with increasing acidity as shown in Figure 1.

Figure 4 shows $U_{\text {cell }}$ as a function of alumina concentration at the two outmost cell conditions in Figure 3, i.e. $w_{\mathrm{AlF}_{3}}=16 \mathrm{wt} . \%\left(T_{\text {bath }}=935^{\circ} \mathrm{C}\right)$ and $w_{\mathrm{AlF}_{3}}=6 \mathrm{wt} . \%$ $\left(T_{\text {bath }}=985^{\circ} \mathrm{C}\right.$ ) at constant ACD. We see that the minimum of the curves changes as a function of bath temperature (and excess $\mathrm{AlF}_{3}$ ). 


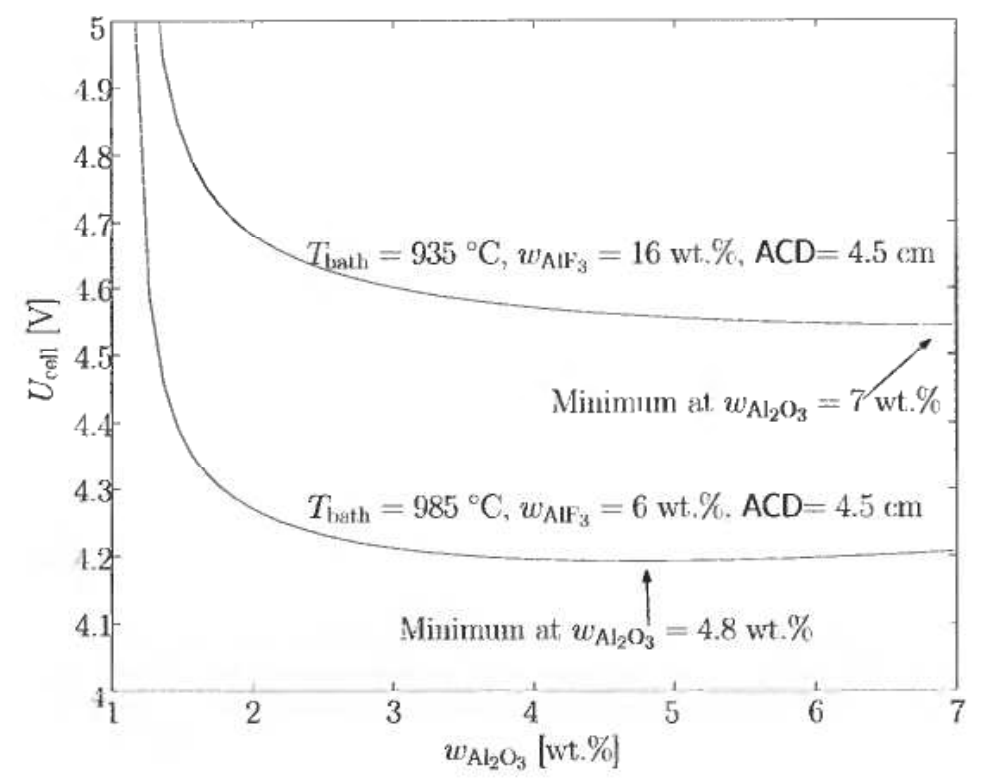

Figure 4. The overall cell voltage as a function of alumina concentration at two different bath temperatures.

The impact on $U_{\text {cell }}$ of the anode beam controller

The result given in Figure 4 is very interesting with respect to the ACD and the anode beam controller. Since the potential $U_{\text {cell }}$ decreases approximately 0.4 volt as the temperature increases from $935^{\circ} \mathrm{C}$ to $985^{\circ} \mathrm{C}$, the anode beam controller would in this situation have increased the ACD in order to maintain the cell potential (or reference resistance) at the setpoint. Hence, the ACD will in hot cells be significantly larger than in cold cells.

In order to determine how much the ACD changes, a simulation including a standard anode beam controller is performed. A standard controller in this context is a controller that maintains the cell voltage or reference resistance at a certain value. The result is shown in Figure 5.

The anode beam controller has in this simulation lifted the anode beam $1 \mathrm{~cm}$ from 4.5 to $5.5 \mathrm{~cm}$. Hence, there is a large degree of freedom in controlling bath temperature by reducing the ACD in hot cells.

\section{Real data}

In order to verify the theoretical results above, real data including anode beam movement and resistance measurements are used to calculate an estimate of the changes in the ACD during a period of almost 2 months. The estimate is based on integrating all the anode beam movements, except those related to metal tapping. Moreover, the anode consumption and the current efficiency are also considered. The result is shown in Figure 6 together with measurements of cathode steel temperature. The reason why cathode steel temperature is used is that this is a continuous measurement representing the dynamics of a cell better than bath temperature measurements taken typically once a day.

As can be seen, the estimate of the changes in ACD is almost as much as $15 \mathrm{~mm}$ 
Impact of Varying Conductivity on the Control of Aluminium Electrolysis Cells 213

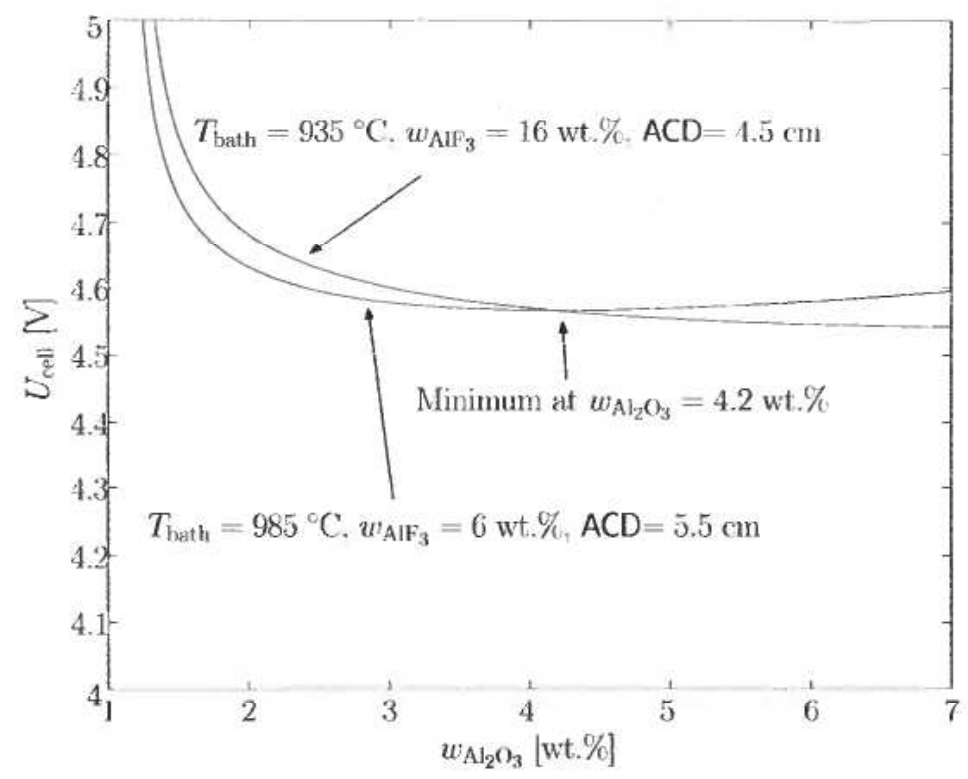

Figure 5. The overall cell voltage as a function of alumina concentration at two different bath temperatures (including the anode beam controller).

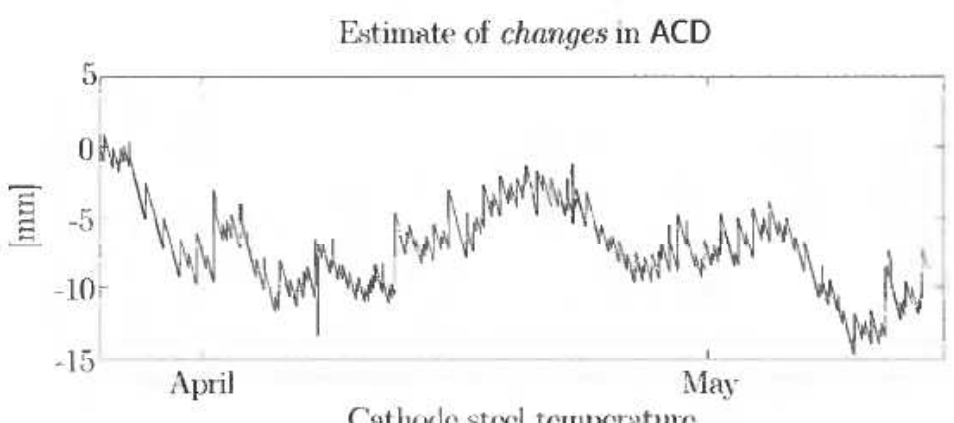

Cathode sted temperature

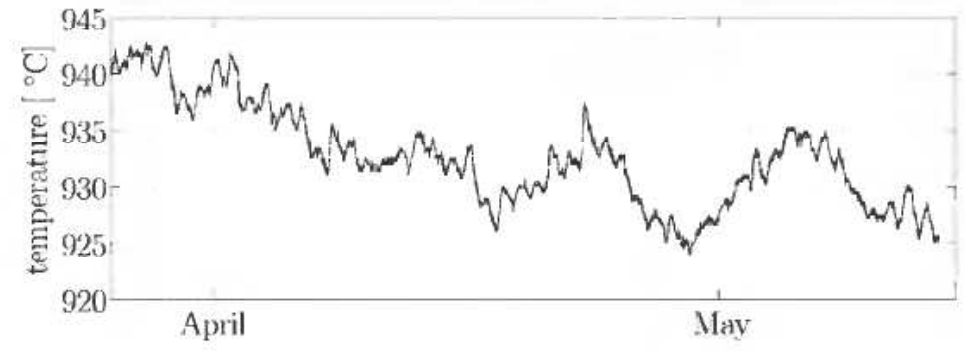

Figure 6. The estimate of changes of ACD and the cathode steel temperature measurements over a period of almost 2 months.

during this period, and the variations coincide with the measured variations in cathode steel temperature.

\section{Control strategy}

As already mentioned, the result in Figure 5 indicates that there is a potential to reduce the ACD in hot cells. However, it should be mentioned that as long as the cell 
is hot, it is believed that the current efficiency is reduced due to increased solubility of aluminum in the electrolyte. Hence, it is probably not possible to reduce the ACD with the entire $1 \mathrm{~cm}$ (for this particular case), since the current efficiency would then probably be reduced (i.e. increased back reaction) causing the cell to become even hotter. Nevertheless, experimental results show that a reduction up to at least $8 \mathrm{~mm}$ in ACD is possible to lower the bath temperature. When analyzing the experienced dynamics of aluminum electrolysis cells, the results from Drengstig et al. (1998) indicated that the variations in both bath temperature and excess $\mathrm{AlF}_{3}$ are found to be caused by disturbances in the energy balance. Hence, a control strategy which is based on an almost constant $\mathrm{AlF}_{3}$ input close to average consumption and energy manipulations, i.e. anode beam movements, to compensate for the energy disturbances is proposed (Drengstig et al., 1998). Thus, the result presented in this paper supports this proposal and it shows that the proposed control strategy is most likely implementable. There are also other means to manipulate the energy balance, though these are often labor intensive, as for instance maintenance of crust thickness.

\section{Influence on the alumina concentration}

As shown in Figure 5, the shape of the $U_{\text {cell }}$ curve changes as the bath temperature changes. Today, most alumina concentration controllers uses the slope of these curves (indirectly found from the measured cell resistance $R_{m}$ ) to estimate the alumina concentration, see e.g. Borg et. al. (1986). Hence, different curve shapes as in Figure 5 will therefore result in different alumina concentration in the cells.

In Figure 7 it is indicated that if the alumina concentration controller is specified to operate at a slope of e.g.

$$
\frac{\partial R_{m}}{w_{\mathrm{Al}_{2} \mathrm{O}_{3}}}=-0.02
$$

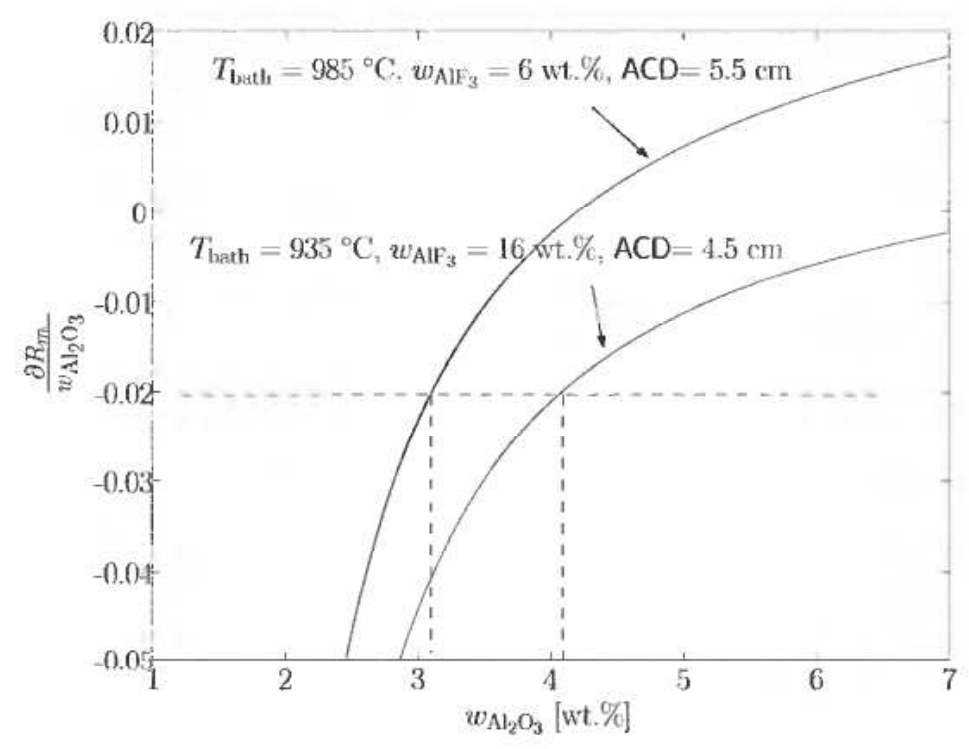

Figure 7. The slope of the curves in Figure 5 found as the partial derivative of the cell resistance with respect to the alumina concentration at two different bath temperatures (including the anode beam controller). 
then the alumina concentration will vary with $1 \mathrm{wt} . \%$ as the temperature varies between $935^{\circ} \mathrm{C}$ and $985^{\circ} \mathrm{C}$.

\section{Discussion}

In this paper the influence of varying cell conditions on cell control is investigated. Cell control here means alumina concentration control, anode beam (cell resistance) control and $\mathrm{AlF}_{3}$ control. The results indicate that a general anode beam controller will increase the anode-cathode distance (ACD) by as much as $1 \mathrm{~cm}$ when the temperature of the cell increases from $935^{\circ} \mathrm{C}$ to $985^{\circ} \mathrm{C}$. The reason for this is that the conductivity of the electrolyte increases as the bath temperature increases, and hence, the anode beam has to be lifted in order to maintain a desired reference resistance. At the same time, the alumina concentration will vary by as much as $1 \mathrm{wt} . \%$ if a general alumina concentration controller, based on changes in cell resistance, is used. Moreover, a control strategy for bath temperature and excess $\mathrm{AlF}_{3}$ is proposed. This is based on reducing the ACD in hot cells, and maintaining the mass balance of $\mathrm{AlF}_{3}$ with almost constant additions of $\mathrm{AlF}_{3}$.

\section{References}

Aaberg, R. J., Ranum, V., Williamson, K. \& Welch, B. J. (1997). The gas under anodes in aluminium smelting cells. Part II: Gas volume and bubble layer characteristics. Light Metals 1997, pp. 341-346.

BORG, P., MOEN, T. \& AALbU, J. (1986). Adaptive control of alumina reduction cells with point feeders. Modelling, Identification and Control, 7(1), 45-56.

Chrenkova, M., Danek, V., Silny, A. \& Utigard, T. A. (1996). Density, electrical conductivity and viscosity of low melting baths for aluminium electrolysis. Light Metals 1996, pp. 227-232.

Danek, V., Chrenková, M. \& SilnÝ, A. (1995). Density and electrical conductivity of melts of the system $\mathrm{Na}_{3} \mathrm{AlF}_{6}-\mathrm{AlF}_{3}$ LiF $\mathrm{Al}_{2} \mathrm{O}_{3}$. The International Harald A. Gye Symposium, pp. 83-94.

Desclaux, P. (1987). $\mathrm{AlF}_{3}$ additions based on bath temperature measurements. Light Metals 1987, pp. $309-313$.

DRENGSTIG, T. (1997). On process model representation and AlF $F_{3}$ dynamics of aluminum electrolysis cells. Dr. ing. thesis, Department of Engineering Cybernetics, Norwegian University of Science and Technology (NTNU), Trondheim, Norway.

Drengstig, T., LJungquist, D. \& Foss, B. A. (1998). On the $\mathrm{AlF}_{3}$ and temperature control of an aluminum electrolysis cell. IEEE Trans. on Control Systems Technology, 6(2), 157-171.

ENTNER, P. M. (1992). Control of AlF concentration. Light Metals 1992, pp. 369-374.

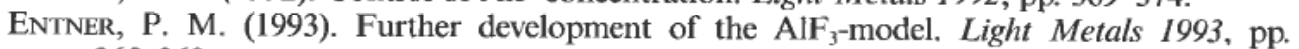
265-268.

ENTNER, P. M. (1995). Control of bath temperature. Light Metals 1995, pp. 227-230.

ENTNer, P. M. \& G. A. Gudmundsson (1996). Further development of the temperature model. Light Metals 1996, pp. 445-449.

GrJotheim, K. \& KVANDE, H., (Eds) (1993). Introduction to aluminium electrolysis-Understanding the Hall-Héroult Process. Aluminium-Verlag, Düsseldorf, Germany, 2 edition.

Haupin, W. (1998). Interpreting the components of cell voltage. Light Metals 1998, pp. $531-537$.

HAUPIN, W. E. (1971). A scanning reference electrode for voltage contours in aluminium smelting cells. Journal of Metals, 23(10), 46-49, October.

Hyde, T. M. \& Welch, B. J. (1997). The gas under anodes in aluminium smelting cells. Part I: Measuring and modeling bubble resistance under horizontally oriented electrodes. Light Metals 1997, pp. 333-340.

PeYneaU, J. M. (1988). The automated control of bath composition on high amperage cell. In Proc. of International Symposiumon on Reduction and Casting of Aluminum, pp. 189. 195, Montreal, Canada. 
Piontelli, R., Mazza, B. \& Pedeferri, P. (1965). Ricerche sui fenomeni anodici nelle celle per alluminio. Metallurgia Italiana, 57(2), 51-69.

TAYLOR, M. P. (1992). Fluoride material balance. In Fourth Australian Aluminium Smelter Technology Workshop, pp. 720-732, Sydney, Australia.

Thonstad, J. \& RolSETH, S. (1978). On the cathodic overvoltage on aluminium in cryolitealumina melts - -I. Electrochimica Acta, 23, 223-231.

WILSON, M. J. (1992). Practical considerations used in the development of a method for calculating aluminium fluoride additions based on cell temperatures. Light Metals 1992, pp. 375-378. 